\title{
Pengaruh Suhu Penyimpanan Obat Kapsul Komersil Terhadap Organoleptik
}

\author{
Effect Of Commercial Capsule Drug Storage Temperature On Organoleptics
}

\author{
Venny Diah Ningsih \\ Program Studi Farmasi, Fakultas Ilmu Kesehatan, Universitas Ibrahimy
}

Email: venny.dingsih@gmail.com

\begin{abstract}
ABSTRAK
Mutu atau kualitas suatu produk obat merupakan faktor penting untuk mengetahui efek terapetik dari suatu obat. Salah satu faktor eksternal yang dapat mempengaruhi mutu obat adalah suhu karena dapat mempengaruhi ketidakstabilan sifat fisikakimia senyawa aktif dalam sediaan. Penelitian ini bertujuan untuk mengetahui pengaruh suhu penyimpanan obat kapsul komersil terhadap organoleptik. Metode penelitian menggunakan pendekatan kuantitatif dan eksperimental dengan cara mengukur kadar asam askorbat dari sampel obat tablet vitamin $\mathrm{C}$ dengan variasi suhu yaitu dingin $\left(5^{\circ} \mathrm{C}\right)$, suhu ruang $\left(27^{\circ} \mathrm{C}\right)$ dan suhu panas berlebih $\left(48^{\circ} \mathrm{C}\right)$ dengan lama waktu simpan 180 menit. Hasil penelitian menunjukkan bahwa suhu berpengaruh secara nyata terhadap kandungan asam askorbat dalam obat tablet vitamin $\mathrm{C}$ komersil dengan hasil pada sampel I suhu dingin $\left(5^{\circ} \mathrm{C}\right) 101.2 \%$, suhu ruang $\left(27^{\circ} \mathrm{C}\right) 97.6 \%$ dan suhu panas berlebih $\left(48^{\circ} \mathrm{C}\right) 90.5 \%$. Pada sampel II suhu dingin $\left(5^{\circ} \mathrm{C}\right) 101.8 \%$, suhu ruang $\left(27^{\circ} \mathrm{C}\right) 103.3 \%$ dan suhu panas berlebih $\left(48^{\circ} \mathrm{C}\right) 95.3 \%$ setelah 180 menit penyimpanan.
\end{abstract}

Kata Kunci: Suhu, Obat Kapsul, Organoleptik

ABSTRACT

Medicinal products have quality standards or qualities that are very important to determine the therapeutic effect of a drug. One of the external factors that affect drug quality is temperature, because temperature can affect the instability of the quality of a drug product. This study aims to determine the effect of storage temperature of commercial capsule drugs on organoleptic. The research method uses a quantitative approach and experimental method by measuring the ascorbic acid content of the vitamin $\mathrm{C}$ tablet drug samples, with variations in temperature, namely cold $\left(5^{\circ} \mathrm{C}\right)$, room temperature $\left(27^{\circ} \mathrm{C}\right)$ and excessive heat $\left(48^{\circ} \mathrm{C}\right)$ for a long time 180 minutes time. The results showed that temperature had a significant effect on the content of ascorbic acid in commercial vitamin $\mathrm{C}$ tablets with the results in sample I cold temperature $\left(5^{\circ} \mathrm{C}\right) 101.2 \%$, room temperature $\left(27^{\circ} \mathrm{C}\right) 97.6 \%$ and overheating temperature $\left(48^{\circ} \mathrm{C}\right) .90 .5 \%$. In sample II the cold temperature $\left(5^{\circ} \mathrm{C}\right)$ was $101.8 \%$, the room temperature $\left(27^{\circ} \mathrm{C}\right)$ was $103.3 \%$ and the overheat temperature $\left(48^{\circ} \mathrm{C}\right)$ was $95.3 \%$ after 180 minutes of storage.

Keywords: Temperature, Capsule Medicine, Organoleptic

\section{PENDAHULUAN}

Mutu obat merupakan
keseluruhan aspek yang dapat
berpengaruh baik secara langsung
maupun tidak langsung terhadap
kualitas, keefektifan dan keamanan
suatu produk obat. Kualitas suatu

produk obat harus sesuai dengan standar mutu dan dapat dikontrol dari berbagai aspek yaitu stabilitas fisik, kimia dan biologi serta mengacu dalam standar atau kriteria yang telah tercantum dalam aturan tentang standar mutu suatu obat. 
Mutu obat dapat dipengaruhi oleh faktor eksternal seperti lingkungan penyimpanan dan suhu. Biasanya suatu produk obat tablet dapat mengalami perubahan mutu saat dalam proses penyimpanan yang diakibatkan oleh suhu ruang penyimpanan. Suhu penyimpanan suatu obat biasanya disimpan pada suhu rendah, suhu ruang dan suhu tinggi. Salah satu produk obat yang harus diperhatikan suhu penyimpanan obatnya adalah produk tablet vitamin $\mathrm{C}$. Tablet vitamin $\mathrm{C}$ mudah teroksidasi pada suhu tinggi, mudah larut dalam air atau memiliki kelembaban yang tinggi, sebagai oksidator, enzim, dan suasana alkali, katalis tembaga dan besi. Proses terjadinya oksidasi vitamin C dapat dihindari dengan penyimpanan produk obat dalam kondisi asam dan suhu rendah (Lestari, 2013). Salah satu kandungan aktif dari tablet vitamin $\mathrm{C}$ adalah asam askorbat. Asam askorbat cenderung kurang stabil dalam suhu ruang sedangkan pada suhu rendah dan tinggi dapat mempercepat terjadinya proses degradasi atau oksidasi (Pavlovska, 2011).

Kurangnya pengontrolan suhu selama proses penyimpanan dan proses distribusi obat tablet vitamin $\mathrm{C}$ dapat berisiko mengganggu mutu atau kualitas sediaan dan bahkan merusak kandungan aktif yang ada dalam sediaan. Solusi saat ini yang dilakukan yaitu memperbaiki formulasi dengan teknologi khusus sehingga kandungan yang tidak stabil dalam tablet vitamin $\mathrm{C}$ lebih stabil dalam berbagai faktor salah satunya pada suhu saat penyimpanan. Penelitian ini bertujuan untuk mengetahui pengaruh suhu penyimpanan obat kapsul komersil tablet vitamin $\mathrm{C}$ terhadap organoleptik.

\section{METODE PENELITIAN}

Penelitian ini merupakan metode eksperimen melalui pendekatan kuantitatif dengan cara mengukur kadar asam askorbat dari sampel tablet vitamin $\mathrm{C}$ setelah disimpan pada suhu dingin $\left(5^{\circ} \mathrm{C}\right)$, suhu $\operatorname{kamar}\left(27^{\circ} \mathrm{C}\right)$ dan suhu panas berlebih $\left(48^{\circ} \mathrm{C}\right)$ masingmasing selama 180 menit. Penelitian ini dilakukan untuk mengetahui pengaruh suhu penyimpanan yang berbeda terhadap organoleptik dan perbedaan kadar asam askorbat. Penelitian dilakukan di Laboratorium Preskripsi Program Studi Farmasi Fakultas Ilmu Kesehatan, Universitas Ibrahimy dan berlangsung pada bulan Agustus 2019. 
Alat yang digunakan meliputi, neraca analitik, gelas beker, pipet tetes, cawan petri, penjepit, spektrofotometri UV-Vis, gelas ukur, corong kaca, mikropipet, pengaduk, kertas saring, tissue, dan alat tulis. Bahan penelitian terdiri dari tablet vitamin $\mathrm{C}$ sampel I (50 $\mathrm{mg} / \mathrm{tab})$, tablet vitamin C sampel II (100 $\mathrm{mg} / \mathrm{tab})$ dan standar vitamin $\mathrm{C}$ (Brataco). Sampel yang digunakan diambil dari Apotek X yang ada di Kota Situbondo dengan menggunakan teknik random sampling atau sampel diambil secara acak.

\section{Uji Organoleptik}

Uji organoleptik yang dilakukan meliputi bentuk, warna, dan bau.

\section{Penetapan Kadar}

Sampel sebanyak 20 tablet dari masing-masing jenis tablet komersil vitamin $\mathrm{C}$ yang telah memenuhi bobot berat disimpan pada suhu rendah yaitu dalam lemari pendingin $\left(5^{\circ} \mathrm{C}\right)$, suhu ruangan yaitu di atas meja $\left(27^{\circ} \mathrm{C}\right)$ dan panas berlebih disimpan dalam oven $\left(48^{\circ} \mathrm{C}\right)$ masing-masing selama 180 menit. Setelah 180 menit, seluruh sampel dikeluarkan dan dilanjutkan pada tahapan selanjutnya.

\section{Pembuatan Larutan Sampel}

Seluruh sampel ditimbang bobotnya untuk mengetahui bobot totalnya, selanjutnya tablet digerus menggunakan mortal dan diperoleh serbuk vitamin C sebanyak $50 \mathrm{mg}$. Serbuk vitamin C dilarutkan dalam 100 $\mathrm{mL}$ akuades menggunakan labu ukur. Larutan kemudian disaring menggunakan kertas saring dan hasil saringannya dilakukan pengenceran kembali dengan cara mengambil sebanyak $2 \mathrm{~mL}$ dan tambahkan akuades hingga $100 \mathrm{~mL}$ pada labu ukur.

\section{Larutan Baku Pembanding}

$50 \mathrm{mg}$ sebuk tablet vitamin $\mathrm{C}$ (standar) ditimbang dan dilarutkan dalam $100 \mathrm{~mL}$ akuades, kemudian dilakukan pengenceran dan dianalisis menggunakan spektrofometri UV-Vis untuk menentukan panjang gelombang maksimumnya.

\section{Cara penetapan kadar sampel}

Serapan larutan sampel dan larutan baku diukur dengan menggunakan spektrofotometer UV-Vis pada panjang gelombang maksimal 266 nm. Larutan blanko yang digunakan adalah akuades. Penetapan kadar sampel diulangi sebanyak 3 kali (triplo) dan hasil pengukuran dihitung 
menggunakan rumus persamaan berikut (Depkes RI, 1979):

Kadar Sampel (\%):

$$
\frac{V u}{V b} \times \frac{F u}{F b} \times \frac{A u}{A b} \times \frac{B r}{B u} \times \frac{B b}{K e} \times 100 \%
$$

Keterangan:

a. $\mathrm{Vu}$ : Volume larutan uji (mL)

b. $\mathrm{Vb}$ : Volume larutan baku $(\mathrm{mL})$

c. $\mathrm{Fu}:$ Faktor pengenceran larutan uji

d. $\mathrm{Fb}$ : Faktor pengenceran larutan baku

e. Au : Absorbansi larutan uji

f. Ab : Absorbansi larutan baku

g. $\mathrm{Br}:$ Bobot rata-rata 1 tablet $(\mathrm{mg})$

h. Bu : Bobot bahan uji yang digunakan $(\mathrm{mg})$

i. Bb : Bobot baku yang ditimbang

j. Ke : Kandungan vitamin $\mathrm{C}$ yang tertera pada etiket (mg)

Data hasil penetapan kadar terhadap seluruh sampel kemudian dianalisa secara statistik dengan metode One Way ANOVA menggunakan program SPSS for Windows. Uji statistik dimaksudkan untuk melihat apakah suhu penyimpanan berpengaruh secara signifikan terhadap kadar asam askorbat dalam tablet vitamin $\mathrm{C}$ komersil, dengan tingkat kepercayaan $95 \%$. Jika ada perbedaan nyata dilanjutkan dengan uji Post Hoc.

\section{HASIL DAN PEMBAHASAN}

Hasil Uji Organoleptik

1. Tablet Vitamin $\mathrm{C}$ sampel I

Tablet vitamin $\mathrm{C}$ yang digunakan :

a. Pabrik : PT. X

b. Kandungan di etiket : $50 \mathrm{mg}$

c. Kemasan sediaan : botol berwarna bening

Hasil Pengamatan :

a. Warna tablet : kuning terang

b. Bau tablet : tidak berbau

2. Tablet Vitamin $\mathrm{C}$ sampel II Tablet vitamin $\mathrm{C}$ yang digunakan :

a. Pabrik : PT. Y

b. Kandungan di etiket : $100 \mathrm{mg}$

c. Kemasan sediaan : kotak berwarna putih

Hasil Pengamatan :

a. Warna tablet : putih bersih

b. Bau tablet : tidak berbau 
Tabel 1. Hasil Absorbansi Vitamin C $(\lambda \max =266 \mathrm{~nm})$

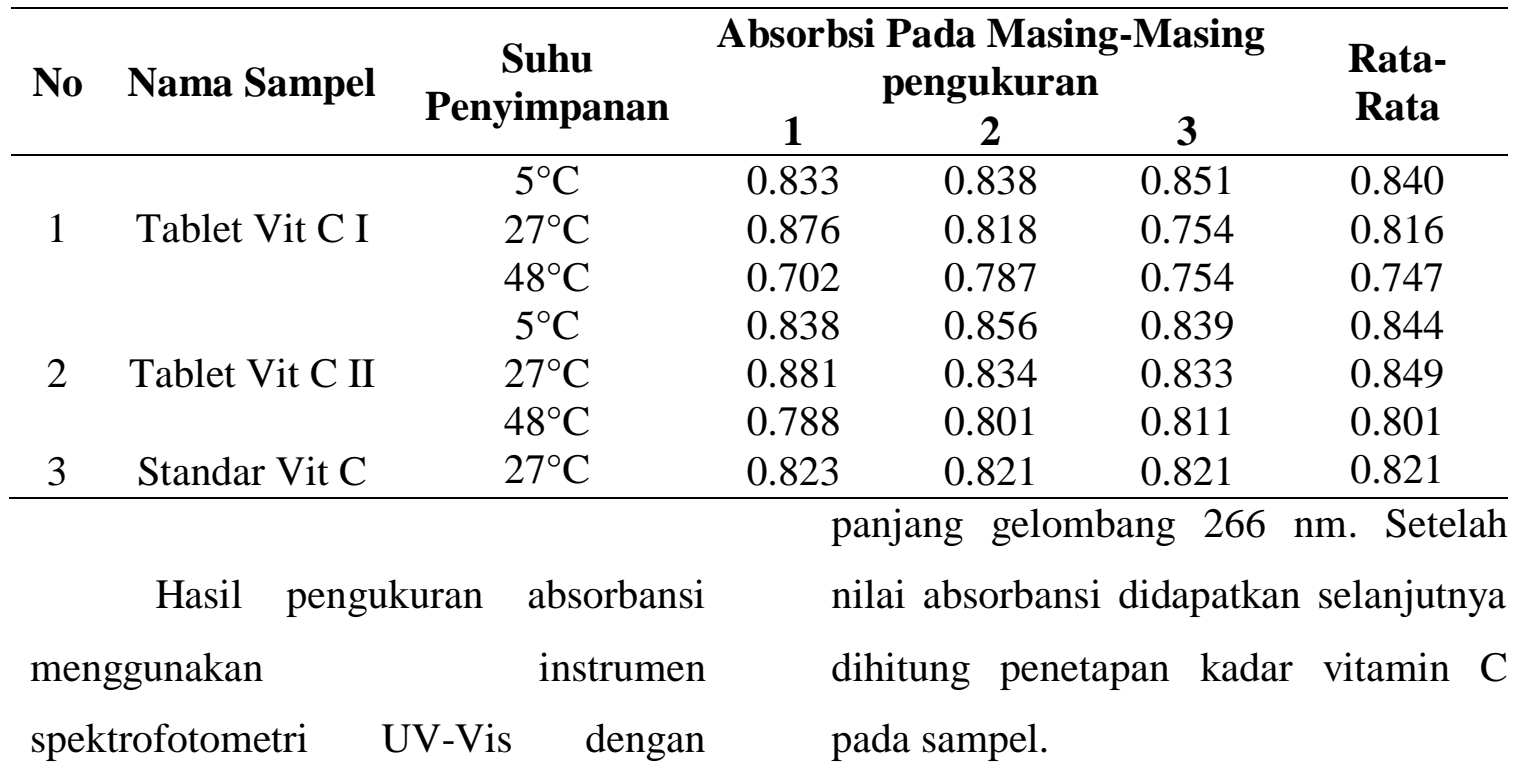

Tabel 2. Hasil Perhitungan Kadar Sampel

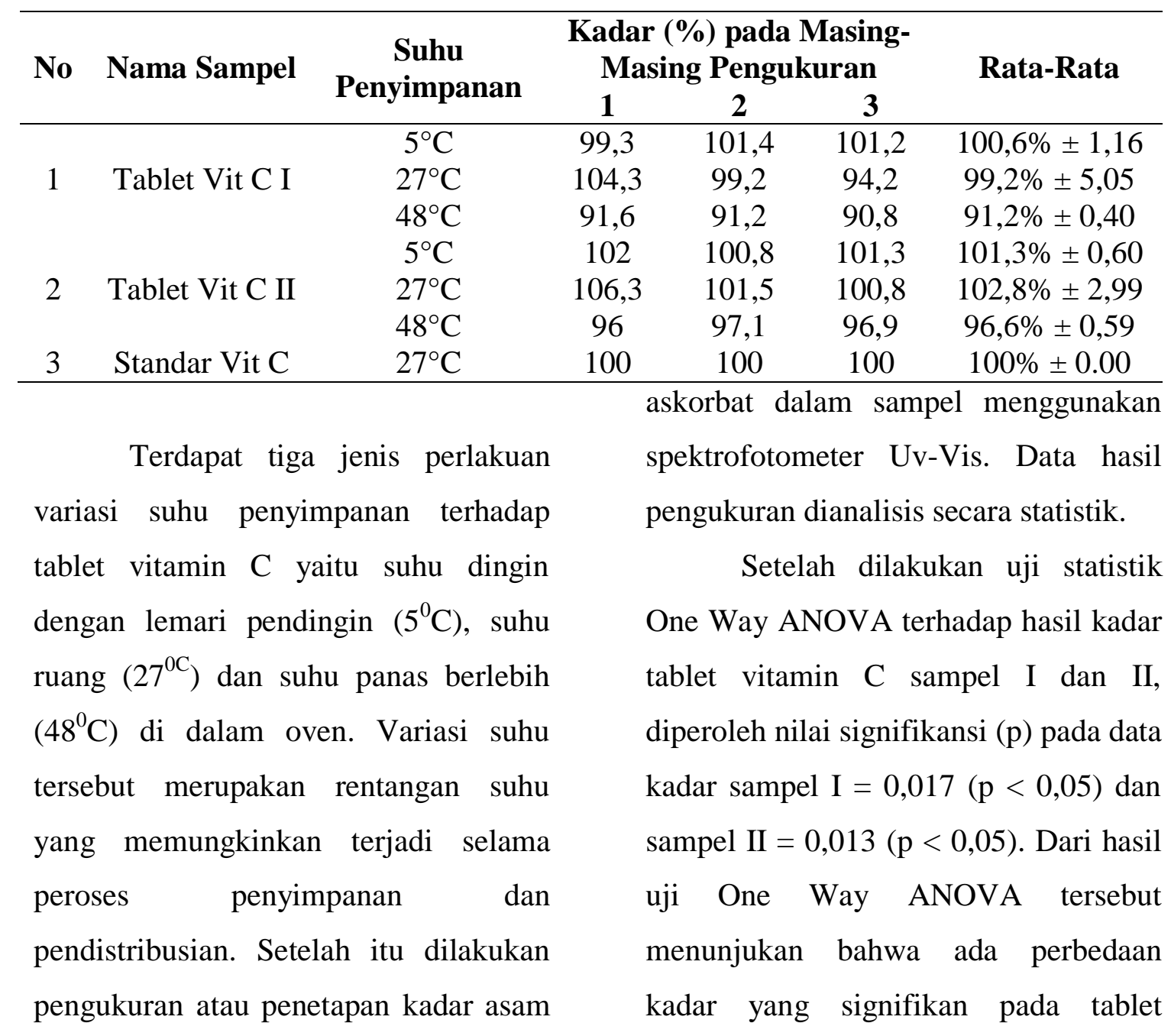


vitamin C sampel I dan II yang disimpan pada suhu $5^{\circ} \mathrm{C}, 27^{\circ} \mathrm{C}$ dan $48^{\circ} \mathrm{C}$. Hal tersebut menunjukkan bahwa suhu penyimpanan berpengaruh signifikan terhadap kadar asam askorbat dalam tablet vitamin C. Setelah dilakukan uji statistik One Way ANOVA dilanjutkan dengan melakukan uji Post Hoc untuk menentukan kelompok perlakuan yang memiliki perbedaan kadar yang signifikan, dan diperoleh hasil bahwa tidak terdapat perbedaan kadar yang bermakna pada tablet vitamin $\mathrm{C}$ sampel I dan II yang disimpan pada suhu dingin $\left(5^{\circ} \mathrm{C}\right)$ dengan suhu kamar $\left(27^{\circ} \mathrm{C}\right)(\mathrm{p}>0,05)$. Sedangkan terdapat perbedaan kadar yang signifikan dari kadar vitamin $\mathrm{C}$ pada tablet yang disimpan pada suhu panas berlebih $\left(48^{\circ} \mathrm{C}\right)$ dengan yang disimpan pada suhu dingin $\left(5^{\circ} \mathrm{C}\right)$ dan suhu kamar $\left(27^{\circ} \mathrm{C}\right)$, seperti yang diuraikan pada tabel 2. Dengan demikian suhu panas dapat berpengaruh signifikan terhadap penurunan kadar asam askorbat dalam sampel tablet vitamin $\mathrm{C}$.

Hasil penelitian ini sejalan dengan hasil penelitian yang dilakukan oleh Pavlovska dan Tanevska (2011) yang menguji pengaruh suhu dan kelembaban terhadap proses degradasi asam askorbat dalam tablet kunyah vitamin $\mathrm{C}$ yang disimpan pada suhu ruang $25{ }^{0} \mathrm{C}$, serta suhu panas $30{ }^{0} \mathrm{C}$ dan $40{ }^{0} \mathrm{C}$ dengan kelembaban tertentu. Proses degradasi yang paling cepat terjadi pada suhu $40{ }^{0} \mathrm{C}$ dibanding dengan suhu ruang. Jadi peningkatan suhu dapat mempercepat terjadinya proses degradasi asam askorbat dalam sediaan tablet vitamin C. Dalam penelitian ini tidak dilakukan pengontrolan kelembaban selama proses perlakuan variasi suhu yang digunakan.

\section{SIMPULAN DAN SARAN}

Suhu penyimpanan dapat berpengaruh secara nyata terhadap kandungan atau kadar asam askorbat dalam sediaan tablet vitamin $\mathrm{C}$ komersil. Kadar tablet vitamin C yang disimpan pada suhu dingin $\left(5^{\circ} \mathrm{C}\right)$ $100,6 \%$, suhu ruang $\left(27^{\circ} \mathrm{C}\right) 99,2 \%$ dan suhu panas berlebih $\left(48^{\circ} \mathrm{C}\right) 91,2 \%$. Sedangkan kadar vitamin C sampel II yang disimpan pada suhu dingin $\left(5^{\circ} \mathrm{C}\right)$ $101,3 \%$, suhu ruang $\left(27^{\circ} \mathrm{C}\right) 102,8 \%$ dan suhu panas berlebih $\left(48^{\circ} \mathrm{C}\right) \quad 96,6 \%$. Pengukuran kadar dilakukan setelah 180 menit penyimpanan pada suhu tersebut. 
Saran pada penelitian ini yaitu supaya bisa menggunakan metode, variasi suhu dan pengukuran kadar menggunakan metode lain dengan berbagai macam obat atau sediaan komersil lainnya.

\section{DAFTAR PUSTAKA}

Depkes RI, 1979, Farmakope Indonesia, Edisi III, Departemen Kesehatan Republik Indonesia, Jakarta.

Lestari N, 2013, Pengaruh Kondisi Penyimpanan Obat Terhadap Kualitas Tablet Vitamin C di Puskesmas Kecamatan Pontianak Kota, Skripsi dipublikasikan, Pontianak, Fakultas Kedokteran Universitas Tanjungpura.

Matei et al, 2008, Kinetic Study of Vitamin C degradation from Pharmaceutical Products, Rom. Journ. Phys., Vol. 53, P. 343351.

Pavlovska, G. \& S. Tanevska, 2011, Influence of Temperature and Humidity on The Degradation Process of Ascorbic Acid in Vitamin C Chewable Tablets, J Therm Anal Calorim DOI 10.1007/s10973-011-2151-z.

Bajaj, S., et al. 2012. Stability testing of Pharmaceutical Products. Journal of Applied Pharmaceutical Science 02(03): 129-138.

BPOM RI. 2012. Pedoman Cara Pembuatan Obat yang Baik. BPOM RI: Jakarta.
BPOM RI. 2013. Petunjuk Operasional Penerapan Pedoman Cara Pembuatan Obat Yang Baik 2012 Jilid I.

BPOM RI: Jakarta. Care Inspectorate. 2016. The Temperature Requirements for Medicine Storages Health Guidance.

Health Canada. 2011. Guideline for Temperature Control of Drug Products During Storage and Transportation GUI-0069.

Health Products and Food Branch Inspectorate. Health Products Regulatory Authority (HPRA). 2017. Guide to Control and Monitoring of Storage and Transportation Temperature Conditions for Medicinal Products and Active Substance. IA-G0011-2.

Priyambodo, B. 2007. Manajemen Farmasi Industri. Yogyakarta: Global Pustaka Utama.

Roy., et al. 2015. Material Managements In Pharmaceutical Industry-A Review. World Journal Of Pharmaceutical Research 4: 1012- 1031.

Shafaat., et al. 2013. An Overview: Storage of Pharmaceutical Products. World Journal Of Pharmacy and Pharmaceutical Science 2: 2499-2515.

Shultz, J., et al. 2007. Standardizing the Storage and Labelling of Medications: Part 2. Can J. Hosp Pharm 60(3): 101-104. 
Wardoyo., dkk. 2016. Wireless Data Logger Suhu Multi Channel Menggunakan Labview. JNTETI 5(2). WHO. 2003. Annex 9 Guide to good storage practices for Pharmaceuticals.

WHO. 2003. WHO Expert Committee on Specification for Pharmaceutical Preparations. Thirty Seventh Report, Geneva, WHO Technical Report Series No. 908 Annex 9.
WHO. 2014. WHO Technical Report Series No. 961. Anex 9: Model Guidance for the Storage and Transport of Time and Temperature Sensitive Pharmaceutical Products.

World Health Organization Press Geneva. USP 35. 2012. General Notices and Requirements: Applying to Standards, Tests, Assays, and Other Specifications of the United States Pharmacopeia. 